\title{
Toward Improving Cooperation in the Americas
}

\author{
Abraham F. Lowenthal ${ }^{\star}$
}

The next US Administration will face many challenges: the wars in Iraq and Afghanistan, Pakistan's possible implosion, conflict with Iran, high energy and food prices, climate change and its effects, the economic growth of China and India and its implications, and the festering IsraelPalestine quandary -not to mention a deepening credit crisis and wider economic recession, turmoil over immigration, growing health care costs, pending decisions on tax and energy policies, decaying infrastructure and the evident need to focus on education, criminal justice reform, competitiveness and other domestic challenges.

No one should expect the new U.S. Administration or the next Congress to give priority to relations with Latin America and the Caribbean. None of the countries of the Americas presents an imminent threat to U.S. national security, none is likely to be the source or target of significant international terrorism and none will be critical to resolving what most regard as the most pressing problems of U.S. foreign policy.

But although the countries of Latin America and the Caribbean pose no urgent issues for the United States, they will be increasingly important to the US future, not as areas of dramatic crisis but in a quotidian way. In fact, Latin America is one of the world regions with the greatest impact on the daily lives of US citizens.

This is true for four main reasons, different from the hoary axioms about Western Hemisphere security, extrahemispheric threats and Pan-American solidarity often cited in the past.

Abraham F. Lowenthal es Profesor de Relaciones Internacionales de la University of Southern California. Asimismo es Presidente Emérito y Senior Fellow del Pacific Council on International Policy, y non-resident Senior Fellow de la Brookings Institution. 
Latin America matters to the United States today, and will matter even more tomorrow, because of:

- Transnational issues that neither the United States nor any Latin American nation can successfully handle by itself, without close and sustained cooperation from regional partners. These include energy security, global warming, pollution and other environmental issues, narcotics, crime and public health.

- Demographic interdependence, arising from massive and sustained migration that has blurred the borders between the United States and its closest neighbors and given rise to complex «intermestic» issues -those with both international and domestic facets- ranging from education to health care, remittances to drivers' licenses, youth gangs to portable retirement pensions.

- Its economic importance to the United States, both as a prime source of energy and other key resources vital for the US economy and as a priority market for the export of U.S. goods and services. The United States obtains over half of its energy imports from countries of the Western Hemisphere and exports $\$ 225$ billion a year in goods to Latin America, four times more than current US exports to China. US firms have, but need to sustain, a competitive advantage in Latin American markets arising from proximity and familiarity plus cultural and demographic ties.

- And shared values, particularly fundamental human rights, including the rights of free political expression, effective democratic governance and consistent application of the rule of law. The American people intuit that these core values cannot prevail internationally if they do not succeed in the Western Hemisphere. At a time when the very difficult experiences in Iraq and elsewhere are discouraging many Americans about the prospects for expanding the influence of US ideals internationally, the shared commitment throughout the Americas to the norms of democratic governance and the rule of law should be increasingly recognized as important.

Despite Latin America's quotidian significance for the United States, US policies toward the region in recent years have been mostly ineffective. Instead of focusing on Latin America's main concerns, Washington has tended to use the prism of international terrorism to deal with Latin America, just as Washington used to make antiCommunism the core of its approach in the Americas. Both the Administrations of Bill Clinton and George W. Bush emphasized Western Hemisphere summits even though these meetings typically produce little beyond photo opportunities. Both Administrations continued to emphasize a proposed Free Trade Agreement for the Americas (FTAA) long after this goal receded from feasibility. Instead of building better bridges toward our closest neighbors, the United States started construction of a border fence at the frontier with 
Mexico. Resentment of the United States, its global policies, and its intermittent attentiveness to the Hemisphere have been building in much of Latin America, only a few years after Western Hemisphere cooperation had seemed to be strengthening.

For their part, various Latin American and Caribbean countries have been diversifying their international relationships, building cooperation with the countries of the European Union, the APEC countries, China, India, Russia and Iran. In many countries of the Hemisphere, there is less inclination than formerly to look to Washington for leadership or even for close cooperation. Western Hemisphere approaches to problem-solving have weakened.

The new U.S. Administration and Congress to take office in January 2009 will have an important opportunity to try to reengage the countries of Latin America and the Caribbean in order to build mutually productive cooperation.

Here are my best suggestions for the consideration of the new U.S. authorities.

1) Rather than promise to pay more attention to Latin America, and then inevitably fall short, the next U.S. Administration and Congress should enhance the quality of the limited attention that can realistically be devoted. Washington should update and improve mindsets and concepts and think more strategically. Instead of offering soaring rhetoric about partnership from
Alaska to Tierra del Fuego, the new Administration should work with Latin American and Caribbean nations on issues that can be addressed soon, such as energy, the environment, crime and education, thus building credibility that has been damaged after years of unfulfilled pledges. Instead of scrambling to counter Hugo Chavez and the «Bolivarian alternative» of anti-U.S. movements, Washington should concentrate on confronting the underlying issues that create space for populist demagogues.

2) The new authorities in Washington should more consistently disaggregate Latin America and the Caribbean. Everyone knows, of course, that Latin American and Caribbean nations vary enormously; this is not new or profound. During the past twenty years, however, there has been a tendency to emphasize convergence within the region: toward democratic governance, market-oriented economics, and policies of macroeconomic balance and regional integration. Although these convergent trends have been important, key differences persist among the countries of Latin America and the Caribbean.

Washington must recognize that some of these differences are growing, not shrinking, along five dimensions:

- Demographic and economic interdependence with the United States -highest and still growing in Mexico, Central America and the Caribbean, 
lowest and likely to remain low in the Southern Cone;

- The extent to which the countries have opened their economies to international competition: by far most fully in Chile, relatively much in Brazil, Colombia, Mexico, Panama, Peru, and some Central American nations; and less so in other countries;

- The strength of democratic governance, including checks and balances, accountability and the rule of law: strong historically in Chile, Uruguay, Costa Rica; increasingly, if quite unevenly, robust in Brazil; gaining ground in Mexico but still being fashioned slowly through hard struggle there; arguably declining, or at least at risk, in Argentina; and under great strain in Venezuela, most of the Andean nations, much of Central America, Haiti and Paraguay;

- The relative effectiveness of civic and political institutions beyond the state: strongest in Chile, Uruguay, Costa Rica and perhaps Argentina; growing but still severely challenged in Brazil and Mexico, slowly regaining stature but still quite problematic in Colombia; weak in Peru, Bolivia, Ecuador, Paraguay and most of Central America; deteriorating in Venezuela; and exceptionally weak in Haiti; and

- The special challenges of integrating more than thirty million marginalized, disadvantaged and increasingly mobilized indigenous people -especially in Bolivia, Ecuador, Guatemala, the Peruvian highlands and southern Mexico- and of incorporating Afro-
Latin Americans as full participants in those countries where they are still the object of racial discrimination.

Only when all these important structural differences and their political consequences are consistently understood can the countries of Latin America and the Caribbean come into clear focus for US policy makers. Hemispherewide summit conferences or broad regional initiatives are less likely to be effective than subregional efforts that bring together those countries with comparable or complementary issues and concerns.

3) Washington must escape the mindsets imposed by ideology and rhetoric in order to grasp the new realities of Latin America and the Caribbean.

For example, instead of dividing Latin America and the Caribbean dichotomously into "democracies" and «dictatorships», Washington needs to realize that the majority of Latin American and Caribbean nations have weak political institutions, low levels of accountability, and highly uneven application of the rule of law. Although the normative goal of democracy has been nearly universally embraced, a welcome advance in the past generation, effective democratic governance and the consistent application of the rule of law remain far from reality in many countries. A central question is whether the United States can help play an appropriate and effective role 
in addressing this issue, at least in some countries.

Instead of promoting free markets and the "Washington Consensus" as the always preferred approach, and citing Chile as the poster-child of this formula, Washington should understand that most Latin Americans see things differently. They point out that Chile's success in fact demonstrates the value of pragmatically combining marketopening reforms with strengthened state capacity, sound public policies and vigorous state action. Some of Latin America's governmental institutions need to become stronger, more competent and more effective -not smaller or weaker- in order to deal with such issues as poverty, inequity, exclusion, crime, personal security and competitiveness. This point needs to be internalized in Washington after a period of excessive faith in markets.

The key distinctions in Latin America today are less whether an economy is market-driven or state-led but rather how well the government and other institutions incorporate feedback and accountability into their decision-making processes, and whether competition among parties and sectors is constructive and energizing or else polarizing and obstructive. Moving toward more democratic politics and economies that are more market-driven certainly can help meet these imperatives, but these trends are not enough without effective institutions, including political parties, and without sufficient state capacity.
4) Four changes in US policy that would have great positive impact in the Americas are strictly speaking not "Latin American policy» issues as such: immigration reform, a revised trade policy, a new emphasis on energy conservation and development, and a fresh approach to the narcotics issue.

- The next US Administration should propose a comprehensive and proactive immigration reform, one that is based on recognizing that labor markets and family dynamics will likely produce substantial immigration flows for the foreseeable future. A new immigration policy should seek to manage and regulate these flows; enhance their benefits to the receiving communities; mitigate, compensate for and more fairly distribute their various costs; and also affirm core US values, including fundamental respect for law.

Any viable plan will require cooperation with Mexico, Central America and the Caribbean on economic, labor, health, education, social, youth employment, law enforcement and infrastructure issues, and thus needs to avoid name-calling and finger-pointing. The new US administration should consult with the Mexican, Central American and Caribbean governments to fashion joint approaches to these transnational issues.

Any feasible and sustainable US immigration policy will include improved border control and management; temporary worker programs; meaningful employer sanctions for those hiring 
unauthorized residents; and concerted efforts at various levels -including practical paths to earned citizenship or else long-term legal residence- to integrate those unauthorized residents who have been contributing to the United States and want to become part of the US community. It will take political leadership and will in both the new Administration and the new Congress to achieve immigration reform, but the need is evident. Immigration reform would be important, not only for the United States but for many other countries of the Americas.

- The negotiations in 2007 between the Bush Administration and Congressional Democratic leadership, and then with the government of Peru, on the Free Trade Agreement with that country may show the way toward reconstructing expanded and sustainable inter-American commercial cooperation. It is not enough simply to stress the benefits of expanded trade for those who prosper while downplaying its costs and risks for others. The United States cannot expect open access for its exports while retaining pockets of strong protectionism for itself, precisely in sectors where developing countries, including Latin American economies, have competitive advantages. More needs to be done to compensate, protect, retrain and provide technical assistance and access to credit to those who are displaced by expanded trade, both in the United States and in the economies of its trading partners, especially in the Americas. Under current conditions, these provisions need to become part of new trade agreements, not just the subject of side accords or of vague promises to deal with the issue later. The next Administration and Congress should work together to win support both from business and labor to keep the United States globally competitive but also to open greater export opportunities to developing countries, including those of Latin America, rather than to intensify targeted protectionism. Latin American countries, for their part, will need to improve protection of labor conditions and workers' rights if trade agreements are to have a prospect for US approval.

- With the price of oil over $\$ 100$ a barrel, declining production of petroleum in Mexico, Venezuela and Ecuador, rapidly rising demands for energy in China and India, geostrategic concerns about the Middle East and Africa, and increased consensus about the harmful impact of carbon emissions, the next Administration and Congress must focus on energy security, including conservation as well as the innovative development of new energy supplies, particularly from renewable sources. The potential is great for important Western Hemisphere cooperation on energy, involving investment in producing oil and natural gas in Mexico, Brazil, Venezuela, Bolivia and Cuba; expansion of nuclear power production in some countries; carefully targeted support for some biofuel development, 
especially sugarcane-based ethanol, in Brazil, Cuba and elsewhere in the Caribbean; investments in wind, hydro and geothermal energy; and collaborative research on both alternative fuels and conservation options.

- The new Administration and Congress, and Latin American governments, should all rethink the "war on drugs». The "war» metaphor should be dropped, because it reinforces the tendencies to look for "victory» against a defined enemy and to favor mainly coercive instruments. Both Washington and Latin American governments should stop emphasizing "narco-terrorists», even though there are undoubtedly nefarious links between traffickers and guerrillas, because the narcotics issue is not really primarily about terrorism or military security. It is rather a complex societal, cultural, medical and institutional problem that has as much to do with deep-seated failures in advanced industrial countries as with weak governance, crime, corruption and poverty in Latin American and other producing nations. The more honestly we all deal with the roots of this destructive business, the more likely is international cooperation to reduce this traffic and to diminish its scope and harm.

The next Administration and Congress should give much higher priority to prevention, treatment, rehabilitation and youth employment programs at home. It should provide more investment in well-structured alternative development and youth employment programs for regions where growing drug crops currently seems like the only alternative to dire poverty, and where local conditions and stakeholders provide some chance for success. It should concentrate less on fumigation of crops and interdiction of shipments and correspondingly more on disrupting both the financial flows and the arms traffic from our country that lubricate and facilitate the drug trade. And it should redouble efforts to constructively engage Latin American and Caribbean cooperation in countering all aspects of this corrosive enterprise, which increasingly damages the whole region.

5) In its policies toward the Americas, the new Administration should concentrate first on the U.S. relationship with Mexico, Central America and the Caribbean. Together these countries account for about a third of the total population of Latin America and the Caribbean but for nearly half of all U.S. investment in the entire region, more than 70 percent of US-Latin American licit trade, and some 85 percent of all Latin American migration to the United States.

Continuing the trends of recent years, Mexico and the Caribbean and Central American nations are likely in the coming decade to become even more fully integrated within the United States. These countries will increasingly use the dollar as their informal and in some cases their official currencies. They will send most of their exports to the United States, and rely overwhelmingly 
on remittances from their diasporas and on U.S. tourists, investment, imports and technology. They will continue to send many migrants northward, and many will accept increasing numbers of retired North Americans as longterm residents as well as large numbers seeking inexpensive medical care and other services. Transnational citizens and networks will grow in importance on such issues as portable international health insurance, extraterritorial applicability for Medicare benefits and bilingual education. All these trends will almost certainly include Cuba, in time.

The intermestic issues that flow directly from the unique mutual interpenetration between the United States and its closest neighbors-immigration, narcotics and arms trafficking, youth gangs, citizen security, auto theft, money-laundering, responding to and mitigating the effects of hurricanes and other natural disasters, protecting the environment and public health, law enforcement and border managementpose complex challenges for policy. The democratic political process, both in the United States and in the neighboring countries, pushes policies on both sides in directions that are often diametrically opposed to what would be needed to secure the international cooperation required to manage thorny problems that transcend borders. Immigration policy is a vivid example; the points scored in the U.S. Congressional debates and approval by Congress of the border fence undoubtedly respond to domestic opinion but by the same token make it harder to work with Mexico and the countries of Central America on immigration and on other issues. This dynamic has also been true of anti-narcotics policy, and of agricultural subsidies that are imposed by domestic lobbies and are difficult to undo, even when they impose disproportionate costs on neighbors.

This dilemma -that the policy approaches most attractive at home often block needed international cooperation- is certainly not limited to the United States. The impulses to place responsibility for tough problems on the other side of the border, and to assert «sovereignty» even when strictly national control is no longer possible in practical terms, are reciprocal and interactive. They present a major challenge, for which existing concepts and institutions are inadequate. The new Administration and Congress should establish official and nongovernmental consultations with counterparts in Canada, Mexico, Central America and the Caribbean on the full range of substantive and institutional challenges posed by increased interdependence in this whole close-knit region. The aim should be nothing less than to forge a shared vision of the whole region's future and of how to achieve it.

6) The second emphasis should be Brazil, where the long-trumpeted future has arrived, or at least is much closer. In the last twenty years, Brazil has opened important parts of its economy 
to international competition, modernized much of its agricultural sector, and developed a number of industries with continental and even world-wide presence. Brazil has slowly but surely strengthened its state, private sector and non-governmental institutions. It has secured financial stability and investment grade status, attracted very substantial foreign investment, and produced steady if still modest economic growth. The recent oil finds reinforce the likelihood that Brazil's growth will accelerate. Together with Chile, Brazil has also begun to reduce absolute poverty and gross inequity, two of the most intractable problems faced by Latin America and Caribbean nations. And Brazil is making notable though still far from sufficient progress in combating corruption, crime, violence, impunity and lack of accountability.

These transformations make it desirable and possible for the United States to work closely with Brazil as a strategic partner. The two countries have many shared interests: enhancing energy security, promoting regional stability, protecting the environment and public health, liberalizing and expanding international trade in agriculture and services, and strengthening global governance. Washington and Brazil should also work together to better manage conflicting international economic and commercial interests by striving to overcome short-term domestic interest group pressures in their respective countries in order to facilitate long-term trade, investment and prosperity. This will not be easy, but an Administration with strategic vision might make some headway if the government of Brazil is ready to do its part.

7) The Andean Ridge nations are quite diverse but all, to differing but invariably high degrees, are plagued by weak political institutions. Most face the unresolved integration of large indigenous populations, and all must address the incorporation of millions of persons, not only indigenous, who live in extreme poverty. Such poverty, gross inequities, social exclusion, rising ethnic and subnational regional consciousness, violence, the weak presence of the state in rural areas and the further undermining of already feeble institutions are a volatile combination. In these circumstances, the mantra that free markets and democratic politics inevitably strengthen and support each other in a powerful virtuous circle simply does not work.

The narcotics trade is at least as much symptom as cause of these conditions; addressing the drug trade in isolation will therefore have little effect. By the same token, combating guerrilla and paramilitary movements through military means alone is unlikely, by itself, to have any enduring impact. Only if and when the underlying and interrelated problems are addressed in integral fashion can the Andean Ridge nations hope to achieve sustained political stability and economic development. Strengthening the state's capacity to provide order depends fun- 
damentally on bolstering its capacity to deliver economic growth, basic services, improved equity, and the consistent application of the rule of law. Nothing the United States can do will substitute for local leadership that deals effectively with all these fundamental problems. Where such leadership emerges, the United States should support their efforts, without being so intrusive as to become part of the problem.

Each of the Andean countries is distinct, their situations are fluid and uncertain, and in some cases they are in conflict with each other. Peru's democratic government has to overcome deep alienation in the country's highland and jungle regions by delivering concrete results, not mere rhetoric or gestures. In Bolivia and Ecuador, efforts to «refound» national identity, build new and more inclusionary political institutions and capture more of the benefits from natural resources face the constraints of the international economy as well as deep suspicion from established national and regional elites and from many middle class professionals. Colombia has made progress in overcoming insurgent movements, restoring urban peace and expanding the influence of institutions but still faces embedded violence and pervasive corruption. And Venezuela is deeply polarized, with Chavez' slowed but by no means assuredly halted march toward more consolidated authoritarian and personal rule on the basis of popular support from sectors previously without voice or influence.
Advancing US interests and the prospects for inter-American cooperation in these complex circumstances requires patient, nuanced, sensitive and case by case treatment, not broad-brush policies. Career diplomats have been increasingly skillful in the latter years of the Bush Administration, for the most part, in managing US relations with the diverse Andean countries by avoiding confrontation and trying to find ways to be constructive. The new Administration would be well-advised to continue this approach and to seek low-key cooperation from like-minded governments in the region.

8) Cuba, however, cries out for fresh US responses to changing circumstances. The long-standing US policy of denial, embargo and exclusion was developed in the Cold War context, and was not demonstrably successful even then. The new Administration and Congress should promptly redefine the objectives of US policy in the light of a fundamentally altered international reality, the ongoing leadership transition in Cuba, the evolution and generational transformation of the Cuban American community, and of broader US interests, beyond the politics of the electoral college.

The primary aim of US policy at this stage should be to increase the likelihood that Cuba and the United States can and will cooperate on their shared concerns-migration, energy, narcotics, the environment, public health, and mitigating hurricanes and 
other natural disasters. At the same time, Washington should do all it can to expand family, academic, and other non-governmental contacts, in order to help rebuild badly frayed communications and trust. As an earnest of its intent and a symbolic step potentially important in other world situations, the new Administration should offer to resume normal diplomatic relations, without preconditions. Pragmatic negotiations should be initiated to find a realistic solution to the claims arising from Cuban expropriations nearly fifty years ago. On the basis of improved communication and expanding practical cooperation, the United States, in concert with other countries, can best support those in Cuba who want to construct democratic institutions and governance, and the Cuban-American community can more likely come to play an important role in the island's economic recovery and development.

9) Perhaps most important, the next US Administration and Congress should understand and explain to the American public why the United States would gain more stable neighbors, expanded markets, more attractive investment opportunities and more congenial tourist destinations if the countries of Latin America and the Caribbean could reduce grinding poverty, gross inequities and ethnic exclusion. These conditions fuel polarization, lend themselves to demagogic exploitation, and undermine both democratic governance and sustainable policies of economic growth and development.

U.S. public policy instruments and available resources today are too limited to make an immediate and dramatic impact on Latin America's poverty, inequity and exclusion; this is not the time to recommend another "Alliance for Progress». But the United States can certainly do much more on this agenda than the pale imitations of the Venezuela-Cuban programs announced on President Bush's 2007 trip to Latin America. Washington can work to enhance the social impact of remittances; support micro-finance programs; and build on the experience of the Millennium Challenge initiative to establish a region-wide social development fund to target poverty reduction efforts and engage especially vulnerable populations, not only in the poorest countries but in the regions of every country where dire poverty exists. It should provide multilateral credit to help energy-importing countries adjust during a period of very high costs; support innovative educational reforms; combat small arms trafficking; and deal with youth gangs as a transnational problem that requires improving education and employing more young people.

Many of these programs already are in place on a modest scale, but the next Administration and Congress should give them additional support; this would not be very expensive and could make a big difference. And Washington should mobilize both public and private sector efforts, in tandem, to strengthen 
infrastructure in Latin America and to expand energy production and distribution-major ways of accelerating the region's growth that are very much in the interest of the United States. On all these issues, multilateral approaches, and particularly redoubled support for the Inter-American Development Bank, are advisable.

10) Finally, and also vitally important, the new Administration and Congress should work together to build mutual respect in the Americas as part of a broader reconsideration of the US role in the world. President George W. Bush traveled to Latin America and the Caribbean more than any other US president, and some specific US policies in the Western Hemisphere during his administration, especially in the second term, have been on the whole positive, if insufficient. But the stature and appeal of the United States in the region have plummeted in recent years because of US policies elsewhere in the world and because the style of US interaction with Latin Americans has so often been dismissive or intrusive: from customs and immigration procedures at the individual level to irksome pressures on Latin American governments on various votes in international organizations.

The next Administration should build upon the unprecedented efforts made by Brazil, Chile and Argentina to help Haiti reverse its decline, and enlist these and other countries to take the lead in building new relations with Cuba. It should warmly welcome Canada's increasing role in the Americas, and should encourage Canada to step forward on some issues and relationships where a high US profile is likely counterproductive. The new Administration should recommit the United States to active support of the Organization of American States and the United Nations. Washington should endorse and adhere to the International Criminal Court, and drop pressures on Latin American nations to grant U.S. personnel exemptions from the Court's jurisdiction. It should engage actively and urgently in global cooperation in response to climate change, and should urge Latin American governments, too, to do their part. Washington should also recognize and celebrate the bicentennial of South American independence in 2010, perhaps by proposing and providing funding and technology for new Western Hemisphere educational initiatives.

More generally, the substance and tone of inter-American relations would be most quickly and substantially improved if the United States returns to a world role that is respectful of international law and opinion, cooperative rather than domineering, committed to multilateralism and international institutions, sensitive to Latin American aspirations for broader international recognition, and true to the fundamental values that are shared by citizens throughout the Americas. The new Administration should make it clear early on that it plans to steer U.S. foreign policy on this course. 